\title{
Presence and Characterization of the Serotonin Transporter in Human Resting Lymphocytes
}

\author{
Donatella Marazziti, M.D., Alessandra Rossi, Dr.Biol.Sci., Gino Giannaccini, Dr.Biol.Sci., \\ Stefano Baroni, Dr.Biol.Sci., Antonio Lucacchini, Dr.Biol.Sci., and Giovanni B. Cassano, M.D., F.R.C.P.
}

\begin{abstract}
Although evidence exists of the presence of a serotonin (5$H T$ ) reuptake system in lymphocytes, no information is available on the pharmacological characterization of this structure. Our study aimed to investigate this matter, therefore, by means of the binding of $\left[{ }^{3} \mathrm{H}\right]$-paroxetine $\left(\left[{ }^{3} H\right] P A R\right)$, a selective $5-H T$ reuptake inhibitor (SSRI), which is considered the ligand of choice for binding studies. Lymphocytes were obtained from a pool of 20 healthy subjects who volunteered for the study. The results showed the presence of a specific and saturable $\left[{ }^{3} H\right] P A R$ binding to lymphocyte membranes, with a Hill number close to unity
\end{abstract}

indicative of the presence of one site only. The most potent drugs inhibiting [ $\left.{ }^{3} \mathrm{H}\right] P A R$ binding were SSRIs (paroxetine, fluoxetine, citalopram) followed by clomipramine, imipramine, and 5-HT, whereas haloperidol, mazindol, and nomifensine had a negligible effect. These findings suggest that $\left.{ }^{3} H\right]-P A R$ in human resting lymphocytes specifically labels the 5-HT transporter.

[Neuropsychopharmacology 19:154-159, 1998]

(C) 1998 American College of Neuropsychopharmacology.

Published by Elsevier Science Inc.
KEY WORDS: Serotonin; Serotonin transporter; Human lymphocytes; Pharmacological characterization;

Antidepressants; SSRIs

The serotonin (5-HT) transporter complex represents one of the main targets of the action of tricyclic antidepressants and selective 5-HT reuptake inhibitors (SSRIs). The transporter subserves the function of removing the neurotransmitter once released in the synaptic cleft and returning it to presynaptic terminals, where it is metabolized by monoaminoxidases or stored in secretory vesicles. Structurally, it belongs to the class of carrier proteins, characterized by 12 hydrophobic membranespanning domains, showing a certain degree of similarity with the GABA and the dopamine transporter (Amara

From the Dipartimento di Psichiatria, Neurobiologia, Farmacologia e Biotecnologie, University of Pisa, Pisa, Italy.

Address correspondence to: Dr. Donatella Marazziti, Dipartimento di Psichiatria, Neurobiologia, Farmacologia e Biotecnologie, University of Pisa, via Roma, 67, 56100 Pisa, Italy.

Received August 6, 1997; revised November 17, 1997; accepted November 25, 1997. and Kuhar 1993; Blakely et al. 1994; Lesch et al. 1994; Merickel et al. 1997).

The most quoted biochemical model of the 5-HT transporter is that of a supramolecular complex with different binding sites, such as those for $\left[{ }^{3} \mathrm{H}\right]$-imipramine $\left(\left[{ }^{3} \mathrm{H}\right] \mathrm{IMI}\right)$, the ligand that has been used to label it for some years (Briley et al. 1979; Ieni et al. 1985; Meyerson et al. 1987). However, pharmacological studies in this field have shown a heterogeneity of $\left[{ }^{3} \mathrm{H}\right] \mathrm{IMI}$ binding sites when desipramine is used to define the "specific" binding (Hrdina 1989): desipramine-defined IMI binding appears to consist of two subpopulations, with only that of a proteic nature, 5-HT-sensitive and Na-dependent being present in serotonergic neurons and related to the 5-HT transporter (Marcusson et al. 1985). [ $\left.{ }^{3} \mathrm{H}\right]$-Paroxetine ([$\left.\left.{ }^{3} \mathrm{H}\right] \mathrm{PAR}\right)$, a SSRI, has subsequently seemed to label the 5-HT transporter protein more specifically (Mellerup et al. 1983; Marcusson et al. 1988), and its use in clinical studies is currently replacing that of $\left[{ }^{3} \mathrm{H}\right] \mathrm{IMI}$ (D'Haenen et al. 1988; Lawrence et al. 1993; Faludi et al. 1994; Maguire et al. 1995; Marazziti et al. 1996). 
The 5-HT transporter has been found and cloned in different tissues, including human brain and blood platelets (Marcusson and Ross 1990; Humphrey et al. 1991; Ramamoorthy et al. 1993a, 1993b; Qian et al. 1995; Padbury et al. 1997), and it appears identical in the two structures, as confirmed by sequence homologies through cloning studies (Blakely et al. 1991; Lesch et al. 1993a,b).

Although evidence exists of the presence of a 5-HT reuptake mechanism in circulating lymphocytes (Faraj et al. 1994), no information is available on the pharmacological characterization of this structure.

Our study aimed, therefore, to investigate the presence of the 5-HT transporter in human resting lymphocytes by means of the specific binding of $\left[{ }^{3} \mathrm{H}\right] \mathrm{PAR}$ and to characterize it pharmacologically.

\section{MATERIALS AND METHODS}

\section{Materials}

[ $\left.{ }^{3} \mathrm{H}\right]$ PAR (specific activity: $20.2 \mathrm{Ci} / \mathrm{mmol}$ ) was purchased from New England Nuclear (NEN, Milan, Italy); 5-HT was obtained from Research Biochemicals Inc. (RBI, Natuck, MA, USA). Imipramine and clomipramine were a gift from Ciba-Geigy AG (Basel, Switzerland); fluoxetine from Eli-Lilly Co. (Indianapolis, IN, USA); paroxetine from SmithKline Beecham Pharmaceuticals (Betchworth, UK) and citalopram from $\mathrm{H}$. Lundbeck A/S (Copenhagen, Denmark); mazindol, nomifensine and haloperidol were purchased from Sigma (Milan, Italy). All other reagents were standard laboratory reagents of analytical grade.

\section{Subjects}

Twenty healthy young subjects (eight female and 12 male; aged between 18 and 30 years; mean age \pm SD: $25 \pm 3$ ) were included. All subjects were drug-free, in good physical health, as documented by a general check-up and by normal blood and urine tests, and with no familial or past personal history of psychiatric or neurological disorders, as assessed by a psychiatric interview. All gave their informed consent to participation in this study, which was approved by the Ethics Committee of Pisa University.

\section{Lymphocyte Preparation}

Venous blood $(50 \mathrm{ml})$ was drawn between 8:00 and 9:00 A.M. from fasting subjects by antecubital venipuncture, collected in heparinized (10 UI/ml blood) plastic tubes and processed immediately. Lymphocytes were isolated according to our modification of the Boyum method (1968). Blood was centrifuged for 15 minutes at $300 \mathrm{~g}$ to obtain a pellet containing red cells, platelets, granulocytes, lymphocytes (P1), and platelet-rich plasma (PRP). Platelets were precipitated from PRP by centrifugation at 30,000 $\mathrm{g}$ for 10 minutes to obtain platelet-free plasma. P1 was diluted 1:1 with Emagel (Behring AG, Marburg) and centrifuged for 30 minutes at $550 \mathrm{~g}$ at room temperature over a density gradient of Lymphoprep (Nycomed, Oslo, Norway). Lymphocytes were harvested and washed in phosphate-buffered saline (PBS) (150 $\mathrm{mmol} / \mathrm{L} \mathrm{NaCl}, 2.5 \mathrm{mmol} / \mathrm{L} \mathrm{KH} 2 \mathrm{PO} 4,11.27 \mathrm{mmol} / \mathrm{L}$ $\mathrm{NaHPO} 4, \mathrm{pH} 7.4$ ) at $300 \mathrm{~g}$ for 15 minutes. The resulting pellet was diluted with $1 \mathrm{ml}$ PBS, stratified on $7 \mathrm{ml}$ of platelet-free plasma and centrifuged at $60 \mathrm{~g}$ for $15 \mathrm{~min}$. Lymphocytes were washed twice in platelet-free plasma to obtain a sample completely separated from platelets. Washed lymphocytes were resuspended in PBS and counted with a hemocytometer. The purity of lymphocyte preparations was controlled by means of an optical microscope (Ortholux, LEITZ) in a Burker chamber. Lymphocytes were colored according to the May-Grunwald methods, and pictures were taken (Figure 1) showing no contamination with other blood elements.

\section{Lymphocyte Membrane Preparation}

The fresh lymphocyte pellet was resuspended in icecold $5 \mathrm{mmol} / \mathrm{L}$ Tris $\mathrm{HCl}$ buffer, $\mathrm{pH}$ 7.4, containing protease inhibitors $(200 \mu \mathrm{g} / \mathrm{ml}$ bacitracine, $160 \mu \mathrm{g} / \mathrm{ml}$ benzamidine, $20 \mu \mathrm{g} / \mathrm{ml}$ soybean trypsin inhibitor), lysed using a Polytron homogenizer and centrifuged at 50,000 $g$ for 10 minutes at $4^{\circ} \mathrm{C}$. The ensuing pellet was resuspended in ice-cold $50 \mathrm{mmol} / \mathrm{L}$ Tris $\mathrm{HCl}$ buffer, $\mathrm{pH}$ 7.4, containing protease inhibitors and centrifuged at 50,000 $\mathrm{g}$ for 15 minutes at $4^{\circ} \mathrm{C}$. The pellet was then washed with $8 \mathrm{ml}$ buffer $(50 \mathrm{mmol} / \mathrm{L}$ Tris $\mathrm{HCl}, 120 \mathrm{mmol} / \mathrm{L} \mathrm{NaCl}, 5$ $\mathrm{mmol} / \mathrm{L} \mathrm{KCl}, \mathrm{pH} 7.4$ ) and stored at $-80^{\circ} \mathrm{C}$ until the assay, which was performed within 2 weeks.

\section{$\left[{ }^{3} \mathrm{H}\right]$ PAR Binding Assay}

On the day of assay, pellets were resuspended and homogenized in an assay buffer of $50 \mathrm{mmol} / \mathrm{L}$ Tris, 120 $\mathrm{mmol} / \mathrm{L} \mathrm{NaCl}, 5 \mathrm{mmol} / \mathrm{L} \mathrm{KCl}$ (pH 7.4) (B1), yielding a final protein concentration of about 50 to $100 \mu \mathrm{g}$ /tube. Proteins were measured according to the Peterson method (1977). The $\left[{ }^{3} \mathrm{H}\right] \mathrm{PAR}$ binding was carried out according to the method of Marazziti et al. (1996). Membranes were incubated in a final volume of $2.0 \mathrm{ml} \mathrm{B1}$ buffer. To test the saturability of $\left[{ }^{3} \mathrm{H}\right] \mathrm{PAR}$ specific binding sites, the lymphocyte membranes were incubated with eight increasing concentrations of $\left[{ }^{3} \mathrm{H}\right] \mathrm{PAR}$, ranging from 0.01 to $1.5 \mathrm{nmol} / \mathrm{L}$. Nonspecific binding was accounted for by incubating similar samples with $10 \mu \mathrm{mol} / \mathrm{L}$ fluoxetine. After 60 minutes at $22^{\circ} \mathrm{C}$, the incubation was halted by the addition of $5 \mathrm{ml}$ of ice-cold B1 buffer. 

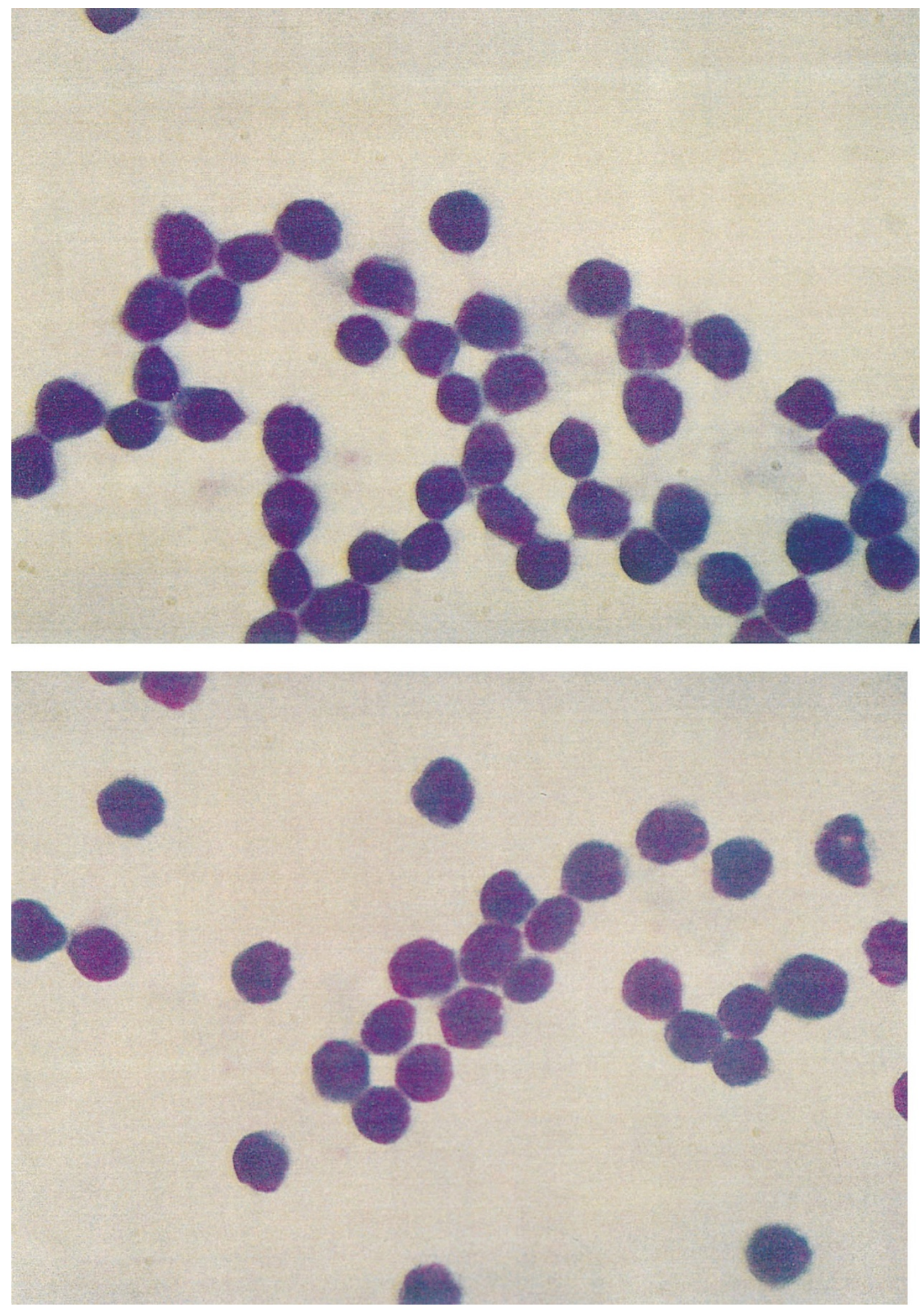

Figure 1. Images of isolated lymphocytes not contaminated by other blood cells. 
Samples were rapidly filtered under vacuum through Whatman GF/C filters previously soaked in polyethylene-immine solution $(0.3 \%)$ and washed three times with $5 \mathrm{ml}$ of assay buffer. Filters were then placed in vials with $4 \mathrm{ml}$ of Ready Protein scintillation cocktail (Beckman), and radioactivity was measured by means of a beta-counter (Packard 1600 Tricarb).

\section{Sodium Dependence}

To assess the sodium dependence, we analyzed also the $\left[{ }^{3} \mathrm{H}\right] \mathrm{PAR}$ binding with a single PAR concentration and varying sodium concentrations. Lymphocyte membranes were preincubated at $22^{\circ} \mathrm{C}$ for 15 minutes in $50 \mathrm{mmol} / \mathrm{L}$ Tris $\mathrm{HCl}$ buffer, then $\left[{ }^{3} \mathrm{H}\right] \mathrm{PAR}(0.15 \mathrm{nmol} / \mathrm{L})$ and $\mathrm{NaCl}$ at concentrations ranging from $100 \mu \mathrm{mol} / \mathrm{L}$ to 500 $\mathrm{mmol} / \mathrm{L}$ were added.

\section{Specificity of $\left[{ }^{3} \mathrm{H}\right]$ PAR Binding}

Lymphocyte membranes were incubated, under the same conditions described above, with a constant concentration of $\left[{ }^{3} \mathrm{H}\right] \mathrm{PAR}(0.4 \mathrm{nmol} / \mathrm{L})$ and eight concentrations, ranging from $0.5 \mathrm{nmol} / \mathrm{L}$ to $10 \mu \mathrm{mol} / \mathrm{L}$, of imipramine and clomipramine (tricyclic antidepressants), paroxetine, fluoxetine, and citalopram (SSRIs), mazindol and nomifensine (compounds with dopaminergic activity), haloperidol (a typical neuroleptic), and 5-HT.

\section{Data Analysis}

The equilibrium-saturation binding parameters, i.e., the maximum binding capacity (Bmax, $\mathrm{fmol} / \mathrm{mg}$ protein) and the dissociation constant, $\left(K_{d}, \mathrm{nmol} / \mathrm{L}\right)$, as well as the drug competition binding data were analyzed by means of the iterative curve-fitting computer programs EBDA and LIGAND (McPherson 1985). The potency of drugs in displacing $\left[{ }^{3} \mathrm{H}\right] \mathrm{PAR}$ was expressed as $\mathrm{Ki}$ values, calculated by means of the formula $\mathrm{Ki}=\mathrm{IC} 50 /(1+$ C/Kd) (Cheng and Prusoff 1973), where IC50 represents the concentration of the drug inhibiting $50 \%$ of the specific radioligand binding and $\mathrm{C}$ is the radioligand concentration.

\section{RESULTS}

Under our experimental conditions described above, the specific $\left[{ }^{3} \mathrm{H}\right] \mathrm{PAR}$ binding represented approximately $75 \%$ of the total binding it was saturable, and of high affinity $\left(K_{d}\right.$, mean $\left.\pm \mathrm{SEM}=0.17 \pm 0.02 \mathrm{nmol} / \mathrm{L}\right)$. The saturation was reached at a concentration of 1 nmol/L of $\left[{ }^{3} \mathrm{H}\right] \mathrm{PAR}$ (Figure 2). The maximum binding capacity (mean \pm SEM) was $220 \pm 26 \mathrm{fmol} / \mathrm{mg}$ protein (Table 1).

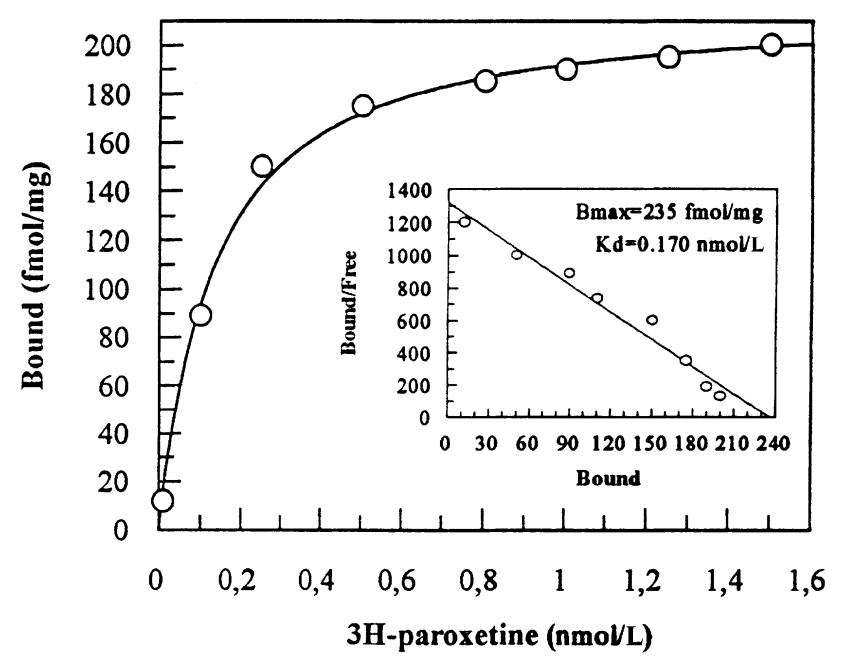

Figure 2. Saturation curve and Scatchard analysis of $\left[{ }^{3} \mathrm{H}\right] \mathrm{PAR}$ binding to lymphocyte membranes.

The Scatchard analysis of the equilibrium saturation binding data resulted in a straight line, consistent with the presence of a homogenous population of binding sites (Figure 2).

With regard to sodium dependence, the results reported in Figure 3 showed that the binding increased significantly with increasing sodium concentrations until the plateau, reached at $110 \mathrm{mmol} / \mathrm{L}$, and that the EC 50 was 70 .

Displacement experiments showed that the tested compounds possessed different degrees of inhibitory potency, the most effective being paroxetine, followed by fluoxetine, citalopram, clomipramine, imipramine, 5-HT, mazindol, nomifensine, and haloperidol (Table 2).

Under our experimental conditions, the displacing curves of the different compounds were all monophasic, with the Hill number close to unity.

\section{DISCUSSION}

The results of our study showed the presence of a high-affinity (in nmol/L order), specific and saturable $\left[{ }^{3} \mathrm{H}\right] \mathrm{PAR}$ binding in membranes obtained from human lymphocytes in resting conditions. The Scatchard analysis and the Hill coefficient close to unity are indicative

Table 1. $\left[{ }^{3} \mathrm{H}\right] \mathrm{PAR}$ Binding Parameters (Bmax and $K_{d}$ ) in Human Lymphocyte Membranes

\begin{tabular}{cccc}
\hline & Age & Bmax & $\boldsymbol{K}_{\boldsymbol{d}}$ \\
\hline $12 \mathrm{M}, 8 \mathrm{~F}$ & $25 \pm 3$ & $220 \pm 26$ & $0.17 \pm 0.02$ \\
\hline $\begin{array}{l}\mathrm{M}=\text { male; } \mathrm{F}=\text { female; Age }=\text { years }(\text { mean } \pm \mathrm{SD}) ; \mathrm{Bmax}=\mathrm{fmol} / \mathrm{mg} \\
\text { protein (mean } \pm \mathrm{SEM}) ; K_{d}=\text { nmol } / \mathrm{L}(\text { mean } \pm \mathrm{SEM}) .\end{array}$
\end{tabular}




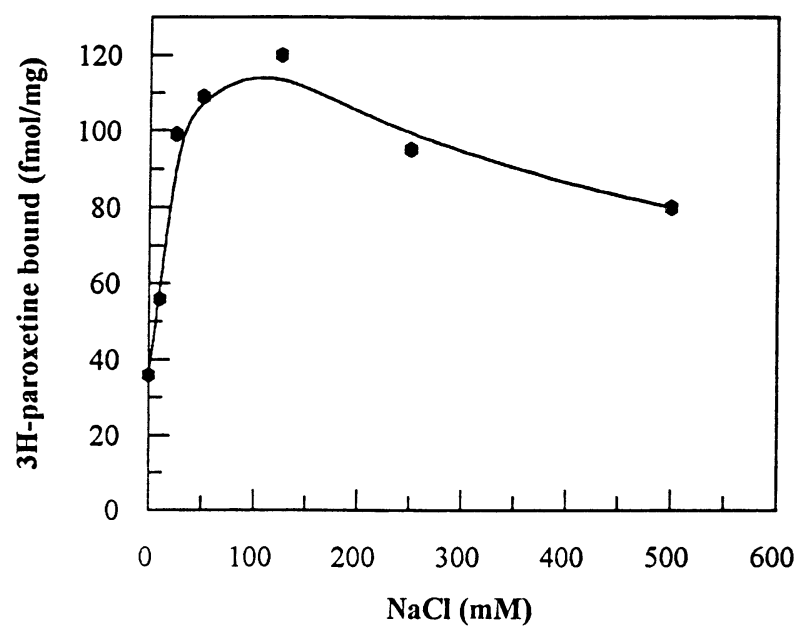

Figure 3. Effect of increasing concentrations of sodium on $\left[{ }^{3} \mathrm{H}\right] \mathrm{PAR}$ binding to lymphocyte membranes. Each point represents the mean \pm SEM of three separate experiments each performed in duplicate.

that $\left[{ }^{3} \mathrm{H}\right] \mathrm{PAR}$ identifies one site only, as already reported in other tissues (Mellerup et al. 1983; Marcusson et al. 1988).

Our findings clearly indicate that $\left[{ }^{3} \mathrm{H}\right] \mathrm{PAR}$ labels the 5-HT transporter protein with the same affinity as that observed in the central nervous system and platelets (Mellerup et al. 1983; Bäckstrom et al. 1989; Rotondo et al. 1996). The results of experiments on sodium dependence showed that $\left[{ }^{3} \mathrm{H}\right] \mathrm{PAR}$ binding required optimal sodium concentration, similar to that found in platelets and brain sections (Mann and Hrdina 1992): this finding also supports the presence of 5-HT transporter in lymphocyte membranes. Although lymphocytes were reported to carry the specific reuptake system for 5-HT (Faraj et al. 1994), the present data may be considered the first demonstration of this structure in human lymphocytes by means of binding techniques.

Further support of the notion that $\left[{ }^{3} \mathrm{H}\right] \mathrm{PAR}$ was labeling the 5-HT transporter derives from the results of

Table 2. Ki (nmol/L) and Hill Number Values of Different Drugs Acting on $\left[{ }^{3} \mathrm{H}\right] \mathrm{PAR}$ Binding to Lymphocyte Membranes

\begin{tabular}{lcc}
\hline Drug & Ki $(\mathbf{n m o l} / \mathbf{L})$ & Hill number $(\mathbf{n H})$ \\
\hline Paroxetine & $0.15 \pm 0.06$ & $1.02 \pm 0.015$ \\
Clomipramine & $1.5 \pm 0.10$ & $0.96 \pm 0.02$ \\
Fluoxetine & $1.87 \pm 0.09$ & $0.99 \pm 0.03$ \\
Citalopram & $4.1 \pm 0.3$ & $0.96 \pm 0.02$ \\
Imipramine & $6 \pm 1.6$ & $0.97 \pm 0.02$ \\
5-HT & $630 \pm 57.3$ & $0.95 \pm 0.03$ \\
Mazindol & $2,000 \pm 162$ & $0.86 \pm 0.04$ \\
Nomifensine & $2,900 \pm 280$ & $0.91 \pm 0.02$ \\
Haloperidol & $3,000 \pm 10$ & $0.92 \pm 0.02$ \\
\hline
\end{tabular}

Each value is the mean \pm SEM of three independent determinations. the pharmacological displacement studies. The most active compound was paroxetine, followed by other SSRIs, fluoxetine, and citalopram in that order. Clomipramine, a nonselective SRI was more active than imipramine, but they were both powerful compounds, whereas 5-HT had a lower effect and mazindol and nomifensine, potent inhibitors of the norepinephrine and the dopamine transporters, and haloperidol had no effect. The pharmacological profile overlapped with that obtained by our group in brain and platelet membranes (Rotondo et al. 1996): in fact, the different compounds showed the same rank of potency in all these tissues. The lack of activity of mazindol and nomifensine at the level of $\left[{ }^{3} \mathrm{H}\right] \mathrm{PAR}$ binding shows that we were not labeling the dopamine transporter, which is present at a high concentration in lymphocytes (Faraj et al. 1991). The presence of the 5-HT transporter in human lymphocytes suggests its possible role in some immune functions, mediated by these cells and by $5-\mathrm{HT}$, whose role as an immunomodulator is currently emerging (Fillion et al. 1996). Although our method of purification of lymphocytes was accurate and we excluded the presence of other blood cells, we did not distinguish B from T lymphocytes: it is thus possible that different lymphocyte subpopulations under different conditions (not activated or activated) might reveal a heterogenous distribution of the 5-HT transporter: future studies should perhaps examine this question.

From a conceptual point of view, the presence of the 5-HT transporter in nucleate cells such as lymphocytes, might permit molecular genetic studies in patients, such as those affected by mood and anxiety disorders, where disturbances at the level of the platelet 5-HT transporter have been reported (Meltzer and Lowy 1987; Marazziti et al. 1996), although it is possible that the regulation of the 5-HT transporter may be different in nucleated and nonnucleated cells. Pursuing this line of research, recently Lesch et al. (1996) showed that a variant of the polymorphism in the 5-HT transporter reduces the expression of the transporter itself and the 5-HT uptake in lymphoblasts. However, the characteristics of the 5-HT transporter in cultured lymphoblasts may differ from those in resting lymphocytes.

\section{REFERENCES}

Amara SG, Kuhar MJ (1993): Neurotransmitter transporter: Recent progress. Annu Rev Neurosci 16:73-93

Bäckstrom IT, Bergstrom M, Marcusson JO (1989): High affinity $\left[{ }^{3} \mathrm{H}\right]$-paroxetine binding to serotonin uptake sites in human brain tissue. Brain Res 486:261-268

Blakely RD, Berson HE, Fremeau RT, Caron MG, Peek MM, Prince HK, Bradley CC (1991): Cloning and expression of a functional serotonin transporter from rat brain. Nature 345:66-70 
Blakely RD, Felice L, Hartzell H (1994): Molecular physiology of norepinephrine and serotonin transporters. J Exp Biol 196:263-281

Boyum A (1968): Isolation of mononuclear cells and granulocytes from blood. Scand J Lab Invest 21:77-85

Briley MS, Raisman R, Langer SZ (1979): Human platelets possess a high affinity binding site for $\left[{ }^{3} \mathrm{H}\right]$-imipramine. Eur J Pharmacol 58:347-348

Cheng YC, Prusoff WH (1973): Relation between the inhibition constant $\mathrm{K}_{\mathrm{i}}$ and the concentration of inhibitor which causes fifty per cent inhibition $\left(\mathrm{IC}_{50}\right)$ of an enzymatic reaction. Biochem Pharmacol 22:3099-3108

D'Haenen H, De Waele M, Leysen JE (1988): Platelet [ $\left.{ }^{3} \mathrm{H}\right]-$ paroxetine binding in depressed patient. Psychiatry Res 26:11-17

Faludi G, Tekes K, Tothfalusi L (1994): Comparative study of platelet $\left[{ }^{3} \mathrm{H}\right]$-paroxetine and $\left[{ }^{3} \mathrm{H}\right]$-imipramine binding in panic disorder patient and healthy controls. J Psychiatry Neurosci 19:109-113

Faraj BA, Olkowski ZL, Jackson RT (1991): Binding of [ $\left.{ }^{3} \mathrm{H}\right]-$ dopamine to human lymphocytes: Possible relationship to neurotrasmitter uptake sites. Pharmacology 42:135-141

Faraj BA, Olkowski ZL, Jackson RT (1994): Expression of a high-affinity serotonin transporter in human lymphocytes. Int J Immunopharmacol 16:561-567

Fillion G, Rousselle JC, Massot O, Zifa E, Fillion MP, Prudhomme N (1996): A new peptide, 5-HT-moduline, isolated and purified from mammalian brain specifically interacts with 5-HT 1B/1D receptors. Behav Brain Res 73:313-317

Hrdina PD (1989): Differences between sodium-dependent and desipramine-defined $\left[{ }^{3} \mathrm{H}\right]$-imipramine binding in intact human platelets. Biol Psychiatry 25:576-584

Humphrey C, Beidler D, Rudnick G (1991): Substrate and inhibitor binding and translocation by the platelet plasma serotonin transporter. Biochem Soc Trans 19:95-98

Ieni JR, Zukhin SR, Van Praag HM (1985): Human platelets possess multiple $\left[{ }^{3} \mathrm{H}\right]$-imipramine binding sites. Eur J Pharmacol 106:669-672

Lawrence KM, Falkowski J, Jacobson RR (1993): Platelet 5-HT uptake sites in depression: three concurrent measures using $\left[{ }^{3} \mathrm{H}\right]$-imipramine and $\left[{ }^{3} \mathrm{H}\right]$-paroxetine. Psychopharmacology 110:235-239

Lesch KP, Wolozin BL, Estler HC, Murphy DL, Riederer P (1993a): Isolation of cDNA encoding the human brain serotonin transporter. J Neural Transm (Gen Sect) 91:67-72

Lesch KP, Wolozin BL, Murphy DL, Riederer P (1993b): Primary structure of the human platelet serotonin uptake site: Identity with the brain serotonin transporter. J Neurochem 60:2319-2322

Lesch KP, Balling U, Gross J, Strauss K, Wolozin BL, Murphy DL (1994): Organization of the human serotonin transporter gene. J Neural Transm 95:157-162

Lesch KP, Bengel D, Heils A, Sabol SZ, Greenberg BD, Petri S, Benjamin J, Muller CR, Hamer DH, Murphy DL (1996): Association of anxiety-related traits with a polymorphism in the serotonin transporter gene regulatory region. Science 274:1527-1531

Maguire KP, Norman TR, Apostolopoulos M, Judd FK, Bur- rows GD (1995): Platelet $\left[{ }^{3} \mathrm{H}\right]$-paroxetine binding in panic disorder. J Affective Disord 33:117-122

Marazziti D, Rossi A, Gemignani A, Giannaccini G, Pfanner C, Milanfranchi A, Presta S, Lucacchini A, Cassano GB (1996): Decreased platelet $\left[{ }^{3} \mathrm{H}\right]$-paroxetine binding in obsessive-compulsive patients. Neuropsychobiology 34 : 184-187

Marcusson JO, Fowler CJ, Hall H, Ross SB, Winblad B (1985): "Specific" binding of $\left[{ }^{3} \mathrm{H}\right]$-imipramine to protease-sensitive and protease-resistant sits. J Neurochem 44:705-711

Marcusson JO, Bergstrom M, Eriksson K, Ross SB (1988): Characterization of $\left[{ }^{3} \mathrm{H}\right]$-paroxetine binding in rat brain. J Neurochem 50:1783-1790

Marcusson JO, Ross SB (1990): Binding of some antidepressants to the 5-hydroxytryptamine transporter in brain and platelets. Psychopharmacology 102:145-155

Mann CD, Hrdina PD (1992): Sodium dependence of $\left[{ }^{3} \mathrm{H}\right]-$ paroxetine binding and 5- $\left[{ }^{3} \mathrm{H}\right]$ hydroxytryptamine uptake in rat diencephalon. J Neurochem 59:1856-1861

McPherson GA, Kinetic, EBDA, LIGAND (1985): Lowry: A Collection of Radioligand Binding Analysis Programs. Cambridge, UK, Biosoft

Mellerup ET, Plenge P, Engelstoft M (1983): High affinity binding of $\left[{ }^{3} \mathrm{H}\right]$-paroxetine and $\left[{ }^{3} \mathrm{H}\right]$-imipramine to human platelet membranes. Eur J Pharmacol 96:303-309

Meltzer HY, Lowy MT (1987): The serotonin hypothesis of depression. In Meltzer HY (ed), Psychopharmacology. New York, Raven Press, pp 513-526

Merickel A, Kaback HR, Edwards RH (1997): Charged residues in transmembrane domains II and XI of a vesicular monoamine transporter form a charge pair that promotes high affinity substrate recognition. J Biol Chem 272:5403-5408

Meyerson LR, Ieni JR, Wennogle LP (1987): Allosteric interaction between the site labelled by $\left[{ }^{3} \mathrm{H}\right]$-imipramine and the serotonin transporter in human platelets. J Neurochem 48:560-565

Padbury JF, Tseng YT, McGonnigal B, Penado K, Stephan M, Rdunick G (1997): Placental biogenic amine transporters: Cloning and expression. Mol Brain Res 45:163-168

Peterson GL (1977): A simplification of the protein assay method of Lowry et al. which is more generally applicable. Anal Biochem 83:356-366

Qian Y, Melikian HE, Rye DB, Levey AI, Blakely RD (1995): Identificaiton and characterization of antidepressantsensitive serotonin transporter protein using site-specific antibodies. J Neurosci 15:1261-1274

Ramamoorthy S, Cool DR, Mahesh VB, Leibach FH, Melikian HE, Blakely RD, Ganapathy V (1993a): Regulation of human serotonin transporter. J Biol Chem 268:21626-21631

Ramamoorthy S, Bauman AL, Moore KR, Han H, Yang-Feng T, Chang AS, Ganapathy V, Blakely RD (1993b): Antidepressant and cocaine human serotonin transporter: Molecular cloning, expression and chromosomal localization. Proc Natl Acad Sci USA 90:2542-2546

Rotondo A, Giannaccini G, Betti L, Chiellini G, Marazziti D, Martini C, Lucacchini A, Cassano GB (1996): The serotonin transporter from human brain: Purification and partial characterization. Neurochem Int 28:299-307 